\title{
Diel feeding migrations in tropical reef fishes
}

\author{
E. S. Hobson \\ Tiburon Fisheries Laboratory; Tiburon, California, USA
}

\begin{abstract}
KURZFASSUNG: Tägliche Futtersuchwanderungen bei tropischen Riffischen. Während der Dämmerungszeiten wandern viele tropische Fische zwischen ihren Ruheplätzen auf dem Riff und ihren Futterplätzen. Diese Wanderungen, die sowohl von tag- als audh von nachtaktiven Fischen durchgeführt werden, sind bedingt durch den Licht-Dunkel-Wechsel, und für viele Arten können sogar Zeit und Weg der Wanderung vorhergesagt werden. Das Muster der tagesrhythmischen Wanderungsbewegungen wird vor allem durch das Ausmaß von Bedrohungen durch Raubfeinde beeinflußt. Bewegungen in ungeschützte Gebiete, die vom Riff wegführen, sind am Tage nicht vorteilhaft. Bei Einbruch der Dunkelheit sind diese offenen Gebiete hingegen ein Konzentrationspunkt der Wanderungen aus dem Riff, wobei sich auch der Zusammenhalt der Fischschwärme verringert. $\mathrm{Da}$ Schwarmverhalten und Schutzsuchen die beiden wichtigsten Verteidigungseinrichtungen gegenüber Räubern darstellen, bedeutet das Aufgeben dieser Verhaltensweisen zu Beginn der Dämmerung, daß während der Nacht kleinere Riffische weniger bedroht sind als wäbrend des Tages. Für wandernde Schwarmfische dürfte eine geringe Variabilität der Verhaltensweisen von adaptiver Bedeutung sein. Nur durch ein koordiniertes Schwarmverhalten ist es offensichtlich möglich, innerhalb bestimmter Grenzen auf die verschieden optischen Marken, welche die Wanderwege kennzeichnen, zu reagieren. Vermutlich spielen die topographischen Gegebenheiten unter Wasser eine entscheidende Rolle für die Orientierung der Riffische.
\end{abstract}

\section{INTRODUCTION}

Diel feeding migrations are widespread among fishes on tropical reefs. Mostly, they are movements between resting locations and feeding grounds. Distances traveled by the different species vary widely, from at least several kilometers to just a few meters; the shorter movements would not be considered migrations except that they are basically the same phenomenon as the more extensive movements. These migrations occur mostly during twilight, as part of a general changeover between the day and night situations. Earlier, I described the twilight transition process in Kona, Hawaii (HOBSON 1972), and contrasted the day and night situations in the Gulf of California (Hobson 1965, 1968); in each of these reports the significance of diel feeding migrations was stressed.

The migrations reflect the differing needs of the fishes during the two major segments of the diel cycle. Most fishes living on tropical reefs are active either by day or by night, with the diurnal species mostly inactive in darkness, and the nocturnal species mostly inactive in daylight (Hobson 1965, 1968, Starck \& Davis 1966). When these fishes are inactive, their behavior relates primarily to their own security; 
when they are active, their actions are dominated by their own feeding (Hosson 1972).

Tropical reef fishes obtain security when inactive in one of two ways: they school or they seek cover (HoBson 1968). The advantages of schooling have been discussed (MANTEIfel \& Radakov 1961, Eibl-Eibeskeldt 1962, Hobson 1968); the advantage of seeking cover is obvious. At least many fishes return to the same schooling or sheltering sites for each period of inactivity (Hobson 1968, 1972). On the other hand, each of the wide variety of fishes on tropical reefs is active in a location that is related to its own specific feeding habits, and which may or may not be near its specific shelter site. Consequently, during the twilight transition period these fishes migrate between feeding grounds and resting locations.

This report is a synthesis of observations made between 1957 and 1972 during a continuous series of research projects at different locations in the Pacific Ocean (Gulf of California, Galapagos Islands, Hawaii and Micronesia). In all these studies, diving equipment was used to observe the fishes in their natural habitats.

\section{CATEGORIES OF DIEL FEEDING MIGRATIONS}

For convenience, the diel feeding migrations can be grouped into three broad, overlapping categories: (1) vertical migrations, (2) intra-reef migrations, and (3) migrations away from the reef. In all, the fishes travel in schools. There is no sharp distinction between these categories, and the activity of many species comprises elements of more than one type; nevertheless, each is characterized separately in the following.

\section{Vertical migrations}

This category includes the many small plankton feeders that move between feeding grounds in the water column, and shelter locations on the reef directly below. Examples include species of Chromis (Pomacentridae) and Parantbias (Serranidae), which are diurnal; and also species of Myripristis (Holocentridae) and Apogon (Apogonidae), which are nocturnal. All these plankton feeders are either diurnal or nocturnal. Without overlap, those feeding in daylight are inactive after dark, and those feeding at night are inactive in daylight (HoBson 1965, 1968, 1972, STARCK \& Davis 1966). Obviously, conditions of plankton feeding differ between day and night. EMERY (1968) described the composition of plankton over Florida reefs as different between day and night. These vertical migrations were discussed earlier (Hobson 1968, 1972), and it was pointed out that one can predict when a given species will rise into the water column or descend to cover.

\section{Intra-reef migrations}

Many fishes travel each day between resting spots and feeding grounds that are widely separated on the reef. The timing and routes followed by many species are 
predictable. Among the more prominent of these are certain herbivores, including certain species of Scarus (Scaridae) and Zebrasoma (Acanthuridae) (Hobson 1972). These, like all herbivorous fishes on tropical reefs, are diurnal (HoBson 1965, 1968, Starck \& Davis 1966). The diel feeding migrations of some plankton feeders include extensive lateral excursions across the reef, in addition to the vertical elements described above; included here are certain species of Naso (Acanthuridae), which are diurnal, and also certain species of Myripristis, which are nocturnal. These intra-reef migrations were discussed earlier (HoBson 1972).

\section{Migrations away from the reef}

The most extensive feeding migrations are performed by the many fishes that pass their inactive hours on the reef and go elsewhere to feed. Off-reef foraging by reef-based fishes is strictly a nocturnal phenomenon. During the day, most fishes in this category school in relatively inactive assemblages on or near the reef. They include certain species of Harengula (Clupeidae), Pranesus (Atherinidae), Lutjanus (Lutjanidae), Haemulon (Pomadasydae), Selar (Carangidae), Sciaena (Sciaenidae) and Mulloidichtbys (Mullidae). Not all fishes in these groups migrate; many disperse at nightfall right at the schooling site, and forage throughout the night in the immediate area on the reef. Nevertheless, the major feeding grounds for diurnally schooling, nocturnally active fishes lie away from the reef. In the Gulf of California, expanses of open sand that lie adjacent to certain reefs are centers of activity for fishes that migrate at nightfall from schooling locations on the reef. However, during the day these same sand flats are accurately described as deserts because so little life is readily seen there (Hobson 1968).

For at least some of these diurnally schooling, nocturnally active fishes, both the timing and route of their off-reef migrations are predictable. In the Gulf of California I was able to predict to within a few minutes in the evening when Harengula thrissina (Clupeidae) would migrate away from its daytime schooling site to feeding grounds offshore. Furthermore, it became possible to chart the route this fish took during its migration (Hobson 1968). We were able to do the same with Pranesus pinguis (Atherinidae) at Majuro Atoll in the Marshall Islands (Hobson \& CHess, in preparation).

The maximum distances traveled during these off-reef migrations vary, and for most species have not been determined. In the tropical western Atlantic Ocean, Haemulon carbonarium (Pomadasyidae) does not migrate, but instead confines its nocturnal foraging to the immediate vicinity of its diurnal schooling site; on the other hand, a congener, $H$. flavoliniatum, ranges at night up to $1.6 \mathrm{~km}$ from where it schools in daylight (StarcK \& Davis 1966). As an example from another family of fishes, Pranesus pinguis ranges up to $1.2 \mathrm{~km}$ from its diurnal schooling sites when it forages after dark in the lagoon at Majuro Atoll (Hobson \& CHEss, in preparation). Swimming underwater in the Gulf of California, I attempted to follow migrating schools of Harengula thrissina as they moved offshore in the evening; however, I always lost contact with them in the growing darkness before traveling more than about 400 $500 \mathrm{~m}$, at which point they had not changed course nor behavior. 
The diurnally schooling, nocturnally active fishes, like all nocturnal reef fishes, are predators (HoBson 1965, 1968). Some that forage away from the reef, for example certain pomadasyids and sciaenids, seek benthic prey. Many others, however, including certain clupeids and atherinids, hunt free-swimming prey, much of it from the plankton. The vast majority of these prey-organisms are invertebrates, mostly crustaceans relatively few fishes are taken (HoBson 1968). Many invertebrate animals, especially small, motile crustaceans, are more abundant in exposed positions at night than during the day (Longley 1927, Hobson 1965, 1968, Starck \& Davis 1966). Earlier I stressed the importance of the relative availability of nocturnal invertebrates in determining activity patterns in tropical reef fishes (Hosson 1968).

\section{FACTORS THAT INFLUENCE THE DIEL FEEDING MIGRATIONS}

\section{The influence of predators}

The daily activities of tropical reef fishes show the overriding influence of two primary concerns: to eat and to avoid being eaten. Even though their own feeding is the primary concern of these fishes during their active periods, their actions, including the pattern of their feeding migrations, can be interpreted as strongly influenced by predators. Schooling and cover-seeking, the means whereby reef fishes attain security during their inactive periods, are also much in evidence during their active periods.

\section{Aggregations in the water column}

The small plankton feeders that forage in the water column characteristically remain in aggregations as long as they are away from the sheltering substrate, and aggregations are judged to provide the same protection as schools - if one wishes to distinguish between these assemblages (Hobson 1968). Furthermore, the distance they move above the reef can be interpreted as strongly influenced by the relative danger from predators. Thus, smaller individuals, which are more vulnerable to predators, do not feed as high in the water column as larger individuals, and when visibility is reduced both large and small remain closer to the reef than otherwise (HoBson 1972). Fish in these aggregations draw themselves close together when threatened; if the danger intensifies they may then dive to the sheltering rocks below. Thus both schooling and the need for proximate cover, as related to their security, influence the feeding activity and related movements of these fishes.

At night the situation is somewhat different. When nocturnal plankton feeders rise above the reef they too aggregate under moonlight, but increasingly disperse on darker nights (Hobson 1965, 1968). Some authors, for example Morrow (1948), have suggested that schools disperse at night because schooling fishes are no longer able to maintain visual contact. However, at least some fishes that have dispersed with darkness readily regroup if threatened, thus demonstrating that they are able to school 
under these conditions if necessary. For example, fishes scattered throughout darkened aquaria immediately formed a tight school when STEvEN (1959) and also ThINES \& VANDENBUSSCHE (1966) introduced an "alarm substance". Clearly, if aggregations are adaptive to such fishes because predation is reduced, then it would seem that the threat from predators diminishes with darkness. Other aspects of the feeding movements of reef fishes lead to this same conclusion, as illustrated below.

\section{Reluctance to leave the reef during daylight}

During the day, lateral excursions among reef fishes in Hawaii are essentially limited to the intra-reef movements of various herbivores and plankton feeders, especially various scarids, acanthurids and pomacentrids (HoBson 1972). Adjacent expanses of open sea floor, like the sand flats that surround many reefs in the Gulf of California, are little visited by reef fishes in daylight. No doubt this in part reflects the relative absence of suitable food in these open areas during the day. Certainly, most herbivores have no reason to range over the open sandy areas, as the vegetation on which they graze is mostly attached to the hard substrates of the reef. However, even in areas where beds of sea grasses lie adjacent to the reef, as in the tropical Atlantic Ocean, diurnal herbivores, mostly scarids and acanthurids, limit their offreef grazing to the periphery of the beds, and thus never range far from the sheltering reef. Their grazing is so intense within this zone that the grasses are effectively cleared away within about $10 \mathrm{~m}$ of the reef. In describing this phenomenon, RANDALI (1965) speculated that these herbivores are kept close to the reef by the threat from predators. A similar situation exists with certain reef fishes that are adapted to feed in the sand, such as certain goatfishes (Mullidae). When sand flats lie adjacent to the reefs, as in the Gulf of California, such fishes frequently range along the periphery of these flats in daylight; however, they stay within retreating distance of the reef during this activity so that shelter is close-by if needed.

Nor can a lack of suitable food fully account for the fact that reef plankton feeders do not range into adjacent open regions during daylight. In the Gulf of California plankton is abundant in the water column above the sand flats surrounding many reefs, and a number of diurnal plankton-feeding fishes are adapted to feeding there. But these are not reef fishes; instead, they are specialized to an existence over the open sand, and all share an ability to find shelter in the only cover available, the sand itself. Thus the eel Taenioconger sp. (Congridae) keeps its tail in its burrow while extending its head as much as $40 \mathrm{~cm}$ up into the water column to pick plankton; when threatened, the eel quickly withdraws into its burrow. The wrasse Hemipteronotus mundiceps (Labridae) is more like the typical reef plankton feeders in that it aggregates up in the water column while feeding on plankton; however, whereas the reef plankton feeders dive to shelter among rocks or coral when seriously threatened, H. mundiceps possesses morphological specializations that allow it to dive headlong into the sand (HoBson 1968). Clearly, in order to feed on plankton in the water column above these exposed, off-reef areas during the day a fish must be able to find effective shelter there when threatened. 
One need not look far to find the predators that so strongly influence the movements of reef fishes. Large carangids and other sizable fish-eaters patrol the inshore waters during the day, and are prominent on most tropical reefs. Nevertheless, in staying close to shelter or in schools the smaller fishes seem relatively secure from these predators during most of the day, even though the predators readily attack when an opportunity presents itself (HoBson 1968). Sometimes large carangids circle slowly about schooling areas in the Gulf of California for hours during the day without making an aggressive move, then instantly attack when some segment of the school has become disorganized, or some individuals isolated (Hobson 1968). Just as schooling fishes tighten up their schools when predators threaten, other reef fishes react to approaching predators by moving closer among reef irregularities, which preclude the space-demanding maneuvers of many large predators. The threat from predators, therefore, is a major reason why open areas are generally avoided by reef fishes in daylight.

\section{Crepuscular period of increased vulnerability}

The large piscivores on the reefs hunt most effectively during twilight (HoBson 1965, 1968, STARCK \& DAvis 1966). However, the migrating fishes - both diurnal and nocturnal - are in their shelter sites when the predators are most active. The diurnal herbivores that had migrated to graze elsewhere on the reef have already returned to their nocturnal resting places, and the diumal plankton feeders have descended to the reef for the night. Furthermore, the nocturnal plankton feeders have not yet ascended into the water column. Thus there is at this time an interim in the twilight transition activities. The same phenomenon occurs during morning twilight, when the sequence of events is reversed. Earlier, I described these evening and morning interim periods in Hawaii, and their relation to the activity of predators (Hobson 1972). The diurnally schooling, nocturnally active fishes, still in their daytime locations and unable to take physical shelter on the reef, are increasingly attadked by the large predators at this time (Hobson 1968). After peaking, the predation ceases, and the predators withdraw. Most of the schooling prey, which are nocturnal predators, then migrate to their offreef feeding grounds (HoBson 1968). This occurs with the approach of last light, suggesting that the mode of attack used by many large piscivores loses its effectiveness when available light falls below a certain level.

\section{Decreased threat from predators at night}

Thus, with nightfall many schooling fishes stream out into the open regions around the reef. Those migrating some distance away remain in a compact school en route, but once on the grounds become increasingly dispersed. Though variably dispersed, the schools of some, for example Microlepidotus inomatus (Pomadasyidae) in the Gulf of California (Hobson 1968), continue to operate as a unit during the night. Others are 
active as solitary individuals, or in small groups. For example, the atherinid Pranestus pinguis swims in a school as it migrates offshore at nightfall in the lagoon of Majuro Atoll; however, during the night, while feeding on plankton at the water's surface, it is widely scattered, with 2-4 m between each individual (HoBSON \& CHEss, in preparation).

Thus, the two suggested mechanisms whereby smaller fishes attain a measure of security against predators during the day - schooling and staying close to shelter become less evident after dark. Not only do small fishes swim freely into exposed regions at night, but, should the need arise, generally they are incapable of taking shelter in the sand. As already stated, this capability seems a requirement of fishes active in these regions during the day. All of this is further evidence that small reef fishes face less of a threat from predators at night than they do during the day.

The schooling fishes that migrate away from the reef at night, like the nocturnal plankton feeders over the reef, described above, are increasingly dispersed on darker nights. Moonlight exerts a strong influence on fishes. RANDALL \& BROCK (1960), among others, suggested that various predominantly diurnal piscivores feed at night when there is a bright moon. The tendency of small fishes to stay closer together under moonlight is probably adaptive for this reason. Certainly, an experienced human is able to operate effectively in clear tropical water at night with no more illumination than moonlight. As moonlight diminishes, so apparently does the danger from fisheating predators.

Some piscivores are adapted to hunt smaller fishes at night. The eastern-Pacific Ocean Caranx marginatus (Carangidae), which may grow to over $600 \mathrm{~mm}$ long, feeds nocturnally (HoBson 1968), and larger individuals of this species are mostly piscivorous. Similarly, Selar crumenopbthalmus and Selene brevoorti, two other carangids, prey on clupeids at night in the Gulf of California (HoBson 1968). These predators are all large-eyed, indicating that they hunt visually after dark, just as most diurnal piscivores do in daylight. Nevertheless, compared to the number of large fish-eating predators abroad in daylight, few seem to be active at night.

Although the behavior of smaller fishes after dark can be interpreted as indicating a diminished threat from piscivores, it is possible that a different sort of predator is afield after dark, one against which schooling or proximate cover offer no protection. MANTEIFEL \& RADAKov (1961) stated that nocturnal predators do not use vision, but rather rely on offaction and lateral-line receptors to locate their prey, finally concluding that the school has no protective value at night. However, I know of no such predator that significantly threatens free-swimming tropical reef fishes. Earlier (HoBsoN 1966, 1968) I discussed visual cues in the sea that could provide targets for visually orienting nocturnal predators.

\section{Importance of activity in numbers}

It is a characteristic of the feeding migrations that the fishes move in schools. Even species that are largely solitary when their activity is confined to a limited area will join with others of their kind when migrating. Probably the advantages of the school 
under this circumstance involves some form of social facilitation. One would expect each individual in a school to be differentially receptive to a given cue, but that member interactions would tend to synchronize the overall response to make actions of the unit more consistent. Thus through group actions fishes are better able to respond with pre-cision to the various cues that regulate their activity. Behavior among fish in a group is less variable than it is among the same number of fish acting independently. WELTY (1934) considered this in his concept of "group cohesion", and it is a well-known charcteristic of fish schools. However, reports on the adaptive significance of schooling have neglected this phenomenon.

The diverse manner in which fishes congregate (e. g. BrEDER 1967) suggests that multiple functions are served - probably more than one simultaneously. The role of fish groups in reducing predation has been extensively dealt with above. Reducing variable behavior seems to be another important function, especially when precise timing or a particular type of response is required in a given stimulus situation. This phenomenon appears especially adaptive to migrating fishes, whose responses to the various cues marking their migration routes may be refined to within acceptable limits by group action. Consider the many species that forage away from the reef during the night. It may be that only through coordinated group action can such fishes navigate in relatively featureless surroundings offshore, and still consistently find their way back to their specific schooling sites at the proper time in the morning.

\section{Importance of submarine landmarks}

Diurnally schooling fishes that swim away from the reef at night tend to return to the same locations each morning, with the daytime schooling sites often located close to prominent topographical features. For example, during observations over six years in the Gulf of California, Haemulon sexfasciatum (Pomadasyidae), which ranged widely when foraging at night, schooled each day close to a particular large rock (HoBson 1968). Certainly a chaotic situation would exist if the many different schools coexisting in a given region, and ranging far afield at night, did not consistently assemble in specific locations when they returned to the reef in the morning. This close association of reef fishes to particular topographical features is not confined to species that migrate. Residency in well-defined locations is characteristic of most reef fishes, as indicated by the tagging efforts of Bardach (1958), Springer \& MCERLEAN (1962), Randall (1961) and others. Probably this involves a mechanism whereby spatial organization is maintained among fishes on the reef. WIILIAMs (1957) and others have suggested that reef fishes determine their position under certain circumstances by orienting on topographical features.

\section{SUMMARY}

1. Many tropical reef fishes that feed during the day rest at night, whereas many that feed at night rest during the day. The feeding grounds of many are some 
distance from their resting grounds. Thus they migrate between these two locations during twilight as part of a general changeover between diurnal and nocturnal situations.

2. At least many of these migrations are predictable, both as to time and to the route taken. The distances traveled vary between species, ranging from just a few meters, to more than several kilometers.

3. The pattern of migrations is strongly influenced by the relative threat from predators at different periods of the diel cycle.

4. During the day, migrations of reef fishes are limited to intra-reef movements: short vertical movements by certain plankton feeders, and lateral excursions from one part of the reef to another by certain herbivores and plankton feeders. Movements into the open regions that lie adjacent to many reefs are not adaptive in daylight due largely to a danger from predators.

5. Despite constant threat from predators during the day, smaller reef fishes remain relatively secure during most of this period by staying close to shelter, or by schooling. However, these defenses are less effective during twilight, when the danger from predators intensifies. The diurnal migrators return to the shelter of their resting places prior to that part of evening twilight when danger is greatest, and the nocturnal migrators usually do not expose themselves for their nightly foraging until after the period of maximum danger has passed. During morning twilight the sequence is reversed.

6. The major mechanisms whereby smaller reef fishes reduce predation during the day - schooling and staying close to shelter - are less evident at night. Not only do reef fishes range freely at night into the open regions that are avoided in daylight, but their schools are more loosely defined, and many are active as solitary individuals or in small groups. The tendency for looser associations and ranging farther afield increases on darker nights.

7. Most predators that threaten reef fishes are visual feeders whose mode of attack loses effectiveness when light falls below a certain level. Although they operate to some extent under moonlight, they threaten small reef fishes less at night than during the day.

8. In addition to whatever other ways a school may be adaptive, by reducing variable behavior among its members the school is especially important to migrating species. Responses to the various cues that mark the migration routes may be refined to within acceptable limits for the population as a whole only by coordinated group action.

9. Submarine topographical features are important reference points for migrating reef fishes.

Acknowledgements. I thank GEORgE BARLow, University of California, for comments on a draft of the manuscript and Walburga Giguere, Tiburon Fisheries Laboratory, for translating the abstract into German. 


\section{LITERATURE CITED}

BARdach, J. E., 1958. On the movements of certain Bermuda reef fishes. Ecology 39, 139-146. BREDER, C. M., 1967. On the survival value of fish schools. Zoologica, N. Y. 52, 25-40.

EIBL-EIbesfeldt, I., 1962. Freiwasserbeobachtungen zur Deutung Fische. Z. Tierpsychol. 19, 165-182.

EmerY, A. R., 1968. Preliminary observations on coral reef plankton. Limnol. Oceanogr. 13 $293 \div 303$.

Hobson, E. S., 1965. Diurnal-nocturnal activity of some inshore fishes in the Gulf of California. Copeia 1965, 291-302.

- 1966. Visual orientation and feeding in seals and sea lions. Nature, Lond. 210, 326-327.

- 1968. Predatory behavior of some shore fishes in the Gulf of California. Res. Rep. U.S. Fish Wildl. Serv. 73, 1-92.

- 1972. Activity of Hawaiian reef fishes during the evening and morning transitions between daylight and darkness. Fish. Bull. U. S. 70, 715-740.

LONGLEY, W. H., 1927. Life on a coral reef. Narn. geogr. Mag. 51, 61-83.

Manterfel, B. P. \& Radakov, D. V., 1961. The adaptive significance of schooling behavior in fishes. Russ. Rev. Biol. 50, 338-345.

Morkow, J. E., 1948. Schooling behavior in fishes. Q. Rev. Biol. 23, 27-38.

Randall, J, E., 1961. Tagging reef fishes in the Virgin Islands. Proc. Caribb. Fish. Inst. 14, 201-241.

- 1965. Grazing effect on sea grasses by herbivorous reef fishes in the West Indies. Ecology $46,255-260$.

- \& BRock, V. E., 1960. Observations on the biology of epinepheline and lutjanid fishes of the Society Islands, with emphasis on food habits. Trans. Am. Fish. Soc. 89, 9-16.

Springer, V. E. \& McErlean A. J., 1962. A study of the behavior of some tagged south Florida coral reef fishes. Am. Midl. Nat. 67, 286-397.

Starck, W. A. \& Davis, W. P., 1966. Night habits of fishes of Alligator Reef, Florida. Ichthyol. Aquar. J. 38, 313-356.

STEven, D. M., 1959. Studies on the shoaling behavior of fish. I. Responses of two species to changes of illumination and to olfactory stimuli. J. exp. Biol. 36, 261-280.

Thines, G. \& VANDEnBussche, E., 1966. The effects of alarm substance on the schooling behavior of Rasbora beteromorpha DunKer in day and night conditions. Anim. Behav. 14, 296-302.

WeLTY, J. C., 1934. Experiments in group behavior of fishes. Physiol. Zoöl. 7, 85-128.

Willirams, G. C., 1957. Homing behavior of California rocky shore fishes. Univ. Calif. Publs Zool. 59, 249-284.

Author's address: Dr. E. S. Horson

Tiburon Fisheries Laboratory

P.O.Box 98

Tiburon, California 94920

USA 